\title{
Value Style Investing Versus Growth Style Investing: Evidence from the 2002-2019 Business Cycle
}

\author{
Mitchell Miller \\ Davenport University \\ Dale Prondzinski \\ Davenport University
}

This paper explores the research question: During the October 2002 to June 2019 time period, which investment strategy, value or growth, produced the better risk-adjusted performance? Risk-adjusted returns were measured using the Sharpe composite performance measure, a measure combining risk and return into a single value. At issue is which style of investing, value versus growth, produces the best rate of return. It is thought that the value style of investing produces a higher, long-term market return than does the growth-style of investing, though long-term returns of both investing styles converge to equilibrium as they regress to their mean [long-term] returns. This study provides a historic and contemporary, conceptual perspective of the value versus growth debate.

Keywords: value style investing vs. growth style investing

\section{INTRODUCTION}

\section{Value Definition and History}

Value investing has been an important part of the equity investment landscape for most of the twentieth century. Value investing is an investment strategy that involves picking stocks that appear to be trading for less than their intrinsic, or book value. Value investing seeks to maximize returns by finding stocks that are undervalued by the market.

Value strategies, credited to Benjamin Graham and David Dodd, have a long history in financial markets, dating to the late 1920s. Graham and Dodd advocated a form of value investing that involved buying profitable, but undervalued assets (Asness, Frazzini, Israel, \& Moskowitz, 2015).

\section{Value Investing as a Strategy}

Value investors actively search for stocks they think the stock market is underestimating. The wellknown 'value premium' argues that value securities, those securities with high book-to-market ratios or low price-to-earnings ratios, outperform other securities when risk-adjusted market returns are considered (Pettengill, Chang, \& Hueng, 2014).

Benjamin Graham articulated five categories of stock investing (as_cited_ _in____acksson,_2 2017) characterizing value investing: General Trading; Selecting Trading; Buying Cheap and Selling Dear; Long-Pull Selection; Bargain Purchases. Value investing continues as a popular, appealing, and enduring 
style of money management. Investing in dividend-paying stocks is one example of a value-style investment strategy.

\section{Computers and CRSP - Source of Benchmark Data}

The reversion to reliance on pricing multiples, such as the price-to book ratio, as a source of identifying value-oriented stocks, gained traction in the 1980s. The price-to-book ratio is important to value investors because it shows the difference between the market value of a company's stock and its book, or intrinsic, value. The market value is the price investors are willing to pay for the stock based on expected future earnings. A key catalyst for the shift to pricing multiples was the introduction of computers and the concurrent development of financial databases, particularly the database of the Center for Research in Security Prices (CRSP).

CRSP was established at the University of Chicago in 1960 for the purpose of introducing the first comprehensive stock market database. Academic research based on the CRSP database initially supported the view that security markets are relatively efficient. This study uses CRSP Large Cap Value Index as a benchmark for U.S. value stocks, and CRSP U.S. Large Cap Growth Index as a benchmark for U.S. growth stocks (Kok, Ribando, \& Sloan, 2017).

\section{Fundamentals of Value Versus Growth}

Two of the most prominent investing styles are value and growth. Value investors target stocks with low multiples; for example, high earnings-to-price ratios and high book-to-price ratios. Growth investors target high multiples (Patel, 2018).

These values mean that a value stock is often perceived to represent a cheap stock, a stock trading at a price lower than its fundamentals. Alternatively, growth stock investment decisions accompany expectations/perceptions of higher earnings and a low price-to-book ratio. Historically, value stocks have outperformed growth stocks; however, since 2007, value stocks have performed relatively poorly, creating an investment 'value trap'.

The authors say the key is to recognize that these multiples are accounting phenomena. To understand the investment risks inherent in these financial ratios, investors need to consider the relationships in the accounting that underpins earnings and book value. The authors argue that there are implications for investors and investment professionals; that investors should be cautious of the standard labeling of 'value and growth' based on buying low- or high-price multiples.

\section{An Explanation for the 'Value Trap'}

A candidate for a value trap investment is a stock that appears to be cheap because the stock has been trading at low valuation metrics (earnings multiples, cash flow, or book value) for an extended period of time. Such a stock attracts investors who are looking for a bargain because the stock seems inexpensive relative to its historical valuation multiples and compared to prevailing market multiples. The value trap happens when investors buy the company stock at low prices, and the stock price continues to languish or decline.

The investment community understands that when one buys a stock, one buys future earnings. Accordingly, price multiples imbed expectations of earnings growth; well recognized is that the earningsto-price ratio $(\mathrm{E} / \mathrm{P})$ or, alternatively, the price-to-earnings ratio $(\mathrm{P} / \mathrm{E})$, indicates the market's expectation of future earnings growth. Less well recognized, however, is that growth can be risky and may not be realized; thus, a stock's price in the earnings-to-price ratio discounts for its risk. Understanding the exposure to this risk is an important decision-factor for an investor buying growth based on a stock's earnings-to-price ratio.

Three points emerge from Penman \& Reggiani's study. First, earnings-to-price ratio and book-toprice ratios are multiples to be used together; these ratios convey important risk and expected return information. Second, when applied jointly with earnings-to-price, a high book-to-price stock, a value stock, indicates higher future earnings growth. Third, the higher growth associated with higher book-to- 
price ratios is risky: high book-to-price stocks are subject to more extreme shocks to growth (Penman \& Reggiani, 2018).

\section{Time Horizon and Diversification Impact}

Scant attention has been given to the impact of time horizon on the risks for value versus growth stocks. Given the growing popularity of value and growth styles of investing, there is a need to analyze the time-changing nature of risks for value versus growth investment styles. The authors found that measures of investing risk decline as the time horizon lengthens. The time benefit is greater for value stocks than for growth stocks; value stocks outperform growth stocks in terms of both long-term risk and return (Wang, 2011).

\section{Margin of Safety}

According to Graham and Dodd, an investment operation should promise safety of principal and a satisfactory return. Operations not meeting these requirements are considered speculative. Investment analysis must be rigorous; second, investment decisions should include an assurance of safety of principal; third, the investment analysis projection should entail an expectation of satisfactory return (Otuteye \& Siddiquee, 2015).

Benjamin Graham further proposed the concept of 'margin of safety' as the cornerstone principle for operationalizing his definition of investment. Margin of safety is a measurement of the degree to which an asset is trading at a discount to its intrinsic value. Thorough analysis enables the investor to obtain an estimate of the intrinsic value of the asset; buying it with a substantial margin of safety ensures safety of principal and an expectation of a satisfactory return. Since intrinsic value is difficult to calculate accurately, margin of safety provides a cushion against making poor investment decisions (Otuteye \& Siddiquee, 2015).

\section{Value Premium and 'Limits to Growth' Hypothesis}

The value-premium is the empirical observation that value stocks, those with a low market-to-book ratio have higher returns than growth stocks, those with a high market-to-book ratio. The 'limits to growth' hypothesis attempts to explain the value premium, which says that firms finance growth internally as profits permit; profitability and growth relate positively. Dividend-paying firms are a good example/test of the 'limits to growth' hypothesis because a firm's limits to growth and investment opportunities are the primary reasons they pay dividends.

\section{Current/Recent Performance: Value Versus Growth}

According to the Russell 1000 index, over the past ten years, growth stocks have extended their performance over value stocks, even as investors have grappled with fear about the economic outlook ("Growth Stocks Get a Boost," 2019).

\section{LITERATURE REVIEW}

\section{Current Economic Environment}

A growing economy defined by a long period of economic expansion (gross domestic product), stock market growth, growing employment, lower taxes, and reduced regulation creates an environment suitable to investment and risk-taking. As of this writing, the United States economic and political policies favor/support strong growth in a weakening global economy. Many economic observers remain concerned that the economic expansion is running out of steam and that the economy is poised for a correction.

Low inflation, political exigencies, and economic pressure suggest that the Fed may reduce interest rates, creating/feeding optimistic investor expectations, sentiment, and behaviors. According to the Russell 1000 index, over the past ten years, growth stocks have extended their performance over value 
stocks, even as investors have grappled with fear about the economic outlook ("Growth Stocks Get a Boost," 2019).

By any measure, growth stocks are beating value stocks in 2019. This year's scoreboard is one-sided with the Russell 1000 Growth index beating the Russell 1000 Value index 20\% to 14\%. The S\&P Barra Growth Index is beating its value counterpart 18\% to 15\%, while the Vanguard Small-Cap Growth ETF is up 21\%, besting the Vanguard Small-Cap Value ETF, is up 16\%.

Much of the stock market's 2019 rally rests on growth sectors such as software, electronics, chips and telecom. While there are no clear topping signals, the market will need a cooling period after a hot streak in the first four months of 2019 (Arancibia, 2019).

\section{Value Definition and History}

Value strategies have had a long and storied history in financial markets. Value strategies date back to the late 1920s and are often credited to Benjamin Graham and David Dodd, who advocated a form of value investing that involved buying profitable, but undervalued assets. Though value investing has been an important part of the equity investment landscape for the better part of the last century, confusion remains in the investment community about value investing (Asness et al., 2015).

The history of value investing is generally traced to Security Analysis, the classic text on the subject by Benjamin Graham and David Dodd (1934). In this book, Graham and Dodd advocate the purchase of stocks trading at a significant discount to their intrinsic value. Graham and Dodd's comprehensive approach to value investing prevailed until the 1980 s, when a reversion to reliance on pricing multiples gained traction (Kok et al., 2017).

Academic interest, in value versus growth investment strategies, was sparked by an influential article by Fama and French (1992). Fama and French tested the notion that U.S. stock prices might be related to the ratio of a firm's book value of common equity to its market value of equity. Fama and French found that companies with high book-to-market equity values outperform the market (Beukes, 2011).

\section{Value Investing as a Strategy}

Strategically, researchers have long studied the relationship between value and growth stocks. Growth stocks are pricey because investors expect fast growth in future expected cash flows. When greed and fear are balanced, as they usually are, value wins, but when investors become overwhelmingly greedy or fearful, growth prevails. Market history supports the notion that long-term investing favors value stocks (Hough, 2011).

Cronqvist, Siegel, \& Yu find that several factors explain an individual investor's strategic style, the value versus growth orientation of the investor's stock portfolio. Some individual investors are relatively value-oriented, while others are growth-oriented. The authors argue that differences in individual investment styles stem from a biological predisposition that translates into a preference for value or growth stocks, and environmental factors that determine an individual's portfolio tilt with respect to value and growth (Cronqvist, Siegel, \& Yu, 2015).

The authors find that an investor's style is explained by life course theory inasmuch as life experiences are related to investment style. Investors with adverse macroeconomic experiences have stronger preferences for value investing later in life, even when differences in income and net worth are accounted for. For example, individuals who grew up during the 1929-1933 Great Depression continue owning value-oriented portfolios. Those who entered the labor market for the very first time during a severe economic recession are also more value-oriented later in life. This evidence contributes to a growing literature in finance and economics, detailing the importance of life experiences and events as determinants of economic behavior later in life (Cronqvist et al., 2015).

Value investors tend to focus their attention on valuing the continuing operations of a firm, while a growth investor tends to look more at the growth opportunities of the companies they invest in. The stock market goes through cycles of varying length that favor either growth or value strategies. Because the market goes in value/growth cycles, these strategies may require a more watchful eye (Jackson, 2017). 
Value investing is all about patience, but the current market cycle is testing the resolve of even the most dedicated disciples of Graham and Dodd (Max, 2019).

\section{Computers and CRSP - Source of Benchmark Data}

A key catalyst for the shift to use of pricing multiples was the introduction of computers and the associated development of financial databases, particularly the database of the Center for Research in Security Prices (CRSP). CRSP was established at the University of Chicago in 1960 to introduce the first comprehensive stock market database. Academic research based on the CRSP database initially supported the view that security markets are largely efficient (Kok et al., 2017).

\section{Fundamentals of Value Versus Growth}

When one buys a stock, one buys future earnings. Accordingly, price multiples imbed expectations of earnings growth; indeed, it is well recognized that the earnings-to-price ratio or, alternatively, the priceto-earnings ratio, indicates the market's expectation of future earnings growth. Less well recognized, however, is that growth can be risky and may not be realized; thus, the price variable (in earnings-toprice) discounts for that risk. Understanding the exposure to this risk is essential for an investor buying growth in an earnings-to-price scenario.

Three points emerge from the authors' study. First, earnings-to-price and book-to-price multiples are used together. Just as earnings and book value articulate value in an accounting sense, earnings-to-price and book-to-price measures convey risk and the expected return for that risk. Second, when applied jointly with earnings-to-price, a high book-to-price value stock indicates higher future earnings growth. Third, the higher growth associated with high book-to-price is risky because high book-to-price stocks are subject to more extreme shocks to growth (Penman \& Reggiani, 2018).

\section{What Is a Value Trap?}

In the world of money management, the term 'value trap' refers to a situation that, superficially, appears to offer an investor the opportunity to acquire significant assets and/or earnings relative to market price, promising a chance at higher-than-average stock market returns, but turns out to be illusionary due to any number of factors.

Value traps can appear for a variety of reasons. Some of the more common situations leading to their development include: a permanent change in the cash generating power of a firm or industry that renders past comparisons useless; a so-called peak earnings trap in cyclical industries with boom-and-bust characteristics; and cash flow issues more severe than indicated by the income.

\section{How You Can Avoid Value Traps or Protect Against Them}

For most investors, the answer to avoiding value traps is avoiding individual stocks entirely because the investor lacks the financial, accounting, and/or managerial skills required to evaluate specific firms. Another idea to avoid/protect against the value trap is to discover the reasons why other owners have been dumping their equity (Penman \& Reggiani, 2018).

\section{Margin of Safety}

The aim of the value philosophy is simply a selection of fundamentally strong shares, with an emphasis on creating a sufficient margin of safety against a possible decline in their prices. This approach

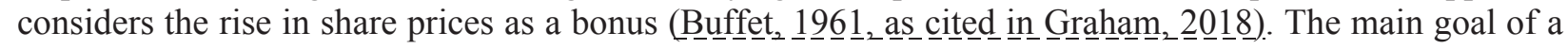
value investor is to maximize a security of portfolio against potential losses.

In contrast with the growth philosophy, which prefers rapidly growing shares, the value approach tries to identify stocks whose profits are currently disappointing for investors, or lacking the interest of investors (Graham, 2018).

The margin of safety concept, introduced by Benjamin Graham in his book The Intelligent Investor (1973), represents a key element in the selection of appropriate value shares. The margin of safety is a 
certain percentage discount with which the share is bought in contrast with its intrinsic value (Kábrt, 2015).

\section{Value Premium and 'Limits to Growth' Hypothesis}

The value-premium is the empirical observation (Fama \& French, as cited in Blazenko \& Fu, 2013) that value stocks (low market/book) have higher returns than growth stocks (high market/book). The authors propose a new explanation for the value premium called the 'limits to growth hypothesis', tested with profitable dividend-paying stocks. The authors posit that a primary reason why businesses pay dividends is the growth limits they face (Blazenko \& Fu, 2013).

\section{Current/Recent Performance: Value Versus Growth}

Over the long haul, value stocks have outpaced growth stocks, evidence of the so-called value premium. However, there are signs of a longer-term change in the relative performance of growth and value stocks. The boundary between growth and value, theoretically two distinct styles of investing, is getting blurrier.

Another theory about why value and growth investing styles are converging is the rise of passive investing. Owing to index-tracking exchange-traded funds like the SPDR S\&P 500 (SPY), substantial amounts of money going is flowing into stocks, obfuscating the ability to distinguish between growth and value, says Goodwin (Strauss, 2015).

A little volatility might be what value stocks. Value stocks, which tend to have slow but steady earnings growth and cheap valuations, vastly underperformed their pricier global growth counterparts in 2017, compounding a gap that has persisted since the end of the financial crisis.

However, if the recent worldwide market swoon is any indication, value stocks could be poised for a comeback, according to an analysis by Morgan Stanley (Russolillo, 2018).

Braham, 2018, indicates that a screen of Morningstar Direct's database indicates that the market is due for a value comeback. The author argues that, for years, the market has been in a slow growth, low interest-rate economy, making investors willing to pay a premium for fast growth; if the economy heats up, cyclical sectors that value investors favor should do well (Braham, 2018).

Conventional wisdom suggests that growth stocks and value stocks go in and out of favor along with the market cycle: growth shines in bull markets, especially in its latter stages, while value takes the lead in bear markets.

Value stocks are those that are trading for the lowest prices relative to their underlying net worth. The metric most often used to determine where a stock falls on the value-growth spectrum is its ratio of price to per-share book value. Value stocks are those with the lowest such ratios, while growth stocks have the highest.

Another reason why many continue to believe that value leads in bear markets is because theories as to why this should be true are so plausible. A stock that is trading for a lower price relative to its intrinsic worth presumably is less likely to fall as far in a bear market than one that is trading for a high price. In a bull market, in contrast, growth stocks should come out ahead since investors are less worried about downside risk (Hulbert, 2018).

Mackintosh notes that value stocks have drastically underperformed over the past 12 years; that value managers are questioning whether value-buying techniques still work. The irony is that over the long run of history, stock bargain hunting has won out by a substantial margin (Mackintosh, 2019).

The dozen years since the great recession have produced numerous theories for why value investing hasn't worked: more efficient markets; quantitative-type investing replacing human emotion; the rise of capital-light companies where traditional value metrics such as price-to-book don't work anymore. Perhaps super-low interest rates have favored fast-growing companies, and thereby punish value stocks. Investors who picked the fast growth companies such as Apple, Google, Microsoft, and Facebook were rightly rewarded. History is compelling and repeats itself; the relative performance of value and growth investing styles will regress to their mean, or average, long-term performance (Mackintosh, 2019). 


\section{DATA AND METHODOLOGY}

\section{Research Question}

The study's primary research question was: During the October 2002 to June 2019 time period, which investment strategy, value or growth, produced the better risk-adjusted performance?

\section{Research Model and Variables}

The study uses CRSP Large Cap Value Index as a benchmark for U.S. value stocks, and CRSP U.S. Large Cap Growth Index as a benchmark for U.S. growth stocks. Risk-adjusted returns were measured using the Sharpe composite performance measure, a measure combining risk and return into a single value. The Sharpe ratio was used to compare the value and growth performance. Morningstar Direct was the database used to obtain the CRSP Large Cap Value and Large Cap Growth indices for the research

\section{Hypotheses}

Four hypotheses, derived from the above research question, were tested.

Complete Time Period

H1 $1_{0}$ For the time period October 2002 to June 2019, the Large Cap Value Index Sharpe ratio is not significantly greater than the Large Cap Growth Index Sharpe ratio.

$H_{1}$ : For the time period October 2002 to June 2019, the Large Cap Value Index Sharpe ratio is significantly greater than the Large Cap Growth Index Sharpe ratio.

Bull Market Time Period

H2 : For the time period October 2002 to September 2007, the Large Cap Value Index Sharpe ratio is not significantly greater than the Large Cap Growth Index Sharpe ratio.

$\boldsymbol{H} 2_{a}:$ For the time period October 2002 to September 2007, the Large Cap Value Index Sharpe ratio is significantly greater than the Large Cap Growth Index Sharpe ratio.

Bear Market Time Period

H3 : For the time period October 2007 to March 2009, the Large Cap Value Index Sharpe ratio is not significantly greater than the Large Cap Growth Index Sharpe ratio.

$\boldsymbol{H}_{a}:$ For the time period October 2007 to March 2009, the Large Cap Value Index Sharpe ratio is significantly greater than the Large Cap Growth Index Sharpe ratio.

\section{Bull Market Time Period}

H40: For the time period April 2009 to June 2019 the Large Cap Value Index Sharpe ratio is not significantly greater than the Large Cap Growth Index Sharpe ratio.

H4 ${ }_{a}$ : For the time period April 2009 to June 2019, the Large Cap Value Index Sharpe ratio is significantly greater than the Large Cap Growth Index Sharpe ratio.

\section{Data Collection Methods}

Secondary data were collected and analyzed from the Morningstar Direct database for the CRSP Large Cap Value and Large Cap Growth indices. The time period selected started at the beginning of the Oct 2002 bull market and culminated in June 2019.

Monthly returns were extracted from the Morningstar Direct database for each index. Standard deviations, the average index returns, and the average risk-free returns were then calculated with the Microsoft Excel computer program using three monthly data points. The Bank of America Merrill Lynch 
3-month monthly Treasury bill returns were used as the risk-free rate to compute the average risk-free returns. These figures were then used to calculate the Sharpe Ratio. The computations yielded 66 data points.

Quarterly data points were extracted and used for each set of paired index comparisons. The quarterly data points of paired indices were exported into the Microsoft Excel computer program spreadsheet. The means, variances, and related risk-adjusted measures of each of the paired indices were calculated, compared, and analyzed.

\section{Data Analysis Methods}

Data analysis was conducted using statistical analyses and hypothesis testing. Each data set was tested for normality using the Kolmogorov-Smirnov test (KS-test) and the Shapiro-Wilk test in the Statistical Package for the Social Sciences (SPSS).

If the KS-test and Shapiro-Wilk test found the data normally distributed, the F-test for two samples for variance was used to test for significant differences between the means of the two indices. If the two tests for normality found the data originated from a non normal distribution, the non-parametric Wilcoxon Signed Rank Test was used to test for significant differences between the means of the two indices. The null hypothesis was rejected if the estimated p-value was less than 0.05 .

\section{RESULTS}

The following details the results and findings of the study's hypotheses tests based on the data extracted from the Morningstar Direct Database and thereby address the study's research question. The findings of the research are presented in the order in which the hypotheses have been stated.

\section{Descriptive Statistics}

Table 1 (Hypothesis 1) provides a comparison of the mean monthly returns, mean quarterly Sharpe Ratios, the standard deviations, and the variances for the CRSP Large Cap Value index against the CRSP Large Cap Growth Index for the 2002-2019 time period. The mean monthly return for the period was lower for the Large Cap Value index return at 0.849 as compared to the Large Cap Growth Index return of 0.961 .

The mean quarterly Sharpe Ratio for the period for the Large Cap Value Index was higher at 0.933 than the Large Cap Growth Index at 0.515. The standard deviation and variance were higher for the Large Cap Value Index. The Large Cap Value Index standard deviation was 3.194 and the variance was 10.203 while the Large Cap Growth index was 0.925 and 0.856, respectively. 
TABLE 1

NUMBER OF DATA POINTS, MONTHLY RETURNS, SHARPE RATIOS, STANDARD

DEVIATIONS, VARIANCES, AND P-VALUES: LARGE CAP VALUE INDEX VERSUS LARGE CAP GROWTH INDEX (2002-2019)

\begin{tabular}{|c|c|c|c|c|c|}
\hline $\begin{array}{c}\text { Number/Returns/Ratios/ } \\
\text { Standard Deviation/Variance/ } \\
\text { P-Value }\end{array}$ & $\begin{array}{l}\text { Hypothesis } \\
\text { Number }\end{array}$ & $\begin{array}{l}\text { Time } \\
\text { Period }\end{array}$ & Index & Index & P-Value \\
\hline & $\mathrm{H} 1_{0}$ & $\begin{array}{l}2002- \\
2019\end{array}$ & $\begin{array}{l}\text { Large Cap } \\
\text { Value }\end{array}$ & $\begin{array}{l}\text { Large Cap } \\
\text { Growth }\end{array}$ & \\
\hline Number of Data Points & & & 66 & 66 & \\
\hline Mean Monthly Return & & & 0.849 & 0.961 & \\
\hline Mean Quarterly Sharpe Ratio & & & 0.933 & 0.515 & \\
\hline Standard Deviation & & & 3.194 & 0.925 & \\
\hline Variance & & & 10.203 & 0.856 & \\
\hline P-Value & & & & & 0.762 \\
\hline
\end{tabular}

Table 2 (Hypothesis 2) provides a comparison of the mean monthly returns, mean quarterly Sharpe Ratios, the standard deviations, and the variances for the CRSP Large Cap Value Index against the CRSP Large Cap Growth Index for the 2002-2007 time period. The mean monthly return for the period was slightly lower for the Large Cap Growth Index than the Large Cap Value Index. The difference between mean monthly returns was 0.047 .

The mean quarterly Sharpe Ratio for the period for the Large Cap Value Index was higher than the Large Cap Growth Index where the value category Sharpe Ratio was 0.776 as compared to the growth category of 0.413 . The Large Cap Value Index standard deviation was 1.316 and the variance was 1.732 while the Large Cap Growth Index was 0.645 and 0.416 , respectively.

TABLE 2

NUMBER OF DATA POINTS, MONTHLY RETURNS, SHARPE RATIOS, STANDARD DEVIATIONS, VARIANCES, AND P-VALUES: LARGE CAP VALUE INDEX VERSUS LARGE CAP GROWTH INDEX (2002-2007)

\begin{tabular}{|cccccc|}
\hline $\begin{array}{c}\text { Number/Returns/Ratios/ } \\
\text { Standard Deviation/Variance/ } \\
\text { P-Value }\end{array}$ & $\begin{array}{c}\text { Hypothesis } \\
\text { Number }\end{array}$ & $\begin{array}{c}\text { Time } \\
\text { Period }\end{array}$ & $\begin{array}{c}\text { Index } \\
\text { Index }\end{array}$ & P-Value \\
\hline & $\mathrm{H} 2_{0}$ & $2002-$ & $\begin{array}{c}\text { Large Cap } \\
\text { Value }\end{array}$ & $\begin{array}{c}\text { Large Cap } \\
\text { Growth }\end{array}$ & \\
\hline Number of Data Points & & 19 & 19 \\
\hline Mean Monthly Return & & 1.289 & 1.242 \\
\hline Mean Quarterly Sharpe Ratio & & 0.776 & 0.413 \\
\hline Standard Deviation & & 1.316 & 0.645 & \\
\hline Variance & & & & 0.416 \\
\hline P-Value & & & & \\
\hline
\end{tabular}

Table 3 (Hypothesis 3) provides a comparison of the mean monthly returns, mean quarterly Sharpe Ratios, the standard deviations, and the variances for the CRSP Large Cap Value Index against the CRSP Large Cap Growth Index for the 2007-2009 time period. The mean monthly return of -2.622 for the 
period was greater for the Large Cap Growth Index as compared to the Large Cap Value Index return of 3.425 .

The mean quarterly Sharpe Ratio for the period for the Large Cap Value Index was higher than the Large Cap Growth Index as the value category Sharpe Ratio was 0.748 as compared to 0.394 for the growth category. The standard deviations and the variances tended to be close arithmetically. The value category's standard deviation was 0.516 and the variance was 0.267 while the growth index's was 0.440 and 0.194 , respectively.

TABLE 3

NUMBER OF DATA POINTS, MONTHLY RETURNS, SHARPE RATIOS, STANDARD DEVIATIONS, VARIANCES, AND P-VALUES: LARGE CAP VALUE INDEX VERSUS LARGE CAP GROWTH INDEX (2007-2009)

\begin{tabular}{|c|c|c|c|c|c|}
\hline $\begin{array}{c}\text { Number/Returns/Ratios/ } \\
\text { Standard Deviation/Variance/ } \\
\text { P-Value }\end{array}$ & $\begin{array}{l}\text { Hypothesis } \\
\text { Number }\end{array}$ & $\begin{array}{c}\text { Time } \\
\text { Period }\end{array}$ & Index & Index & P-Value \\
\hline & $\mathrm{H} 3_{0}$ & $\begin{array}{l}2007- \\
2009\end{array}$ & $\begin{array}{l}\text { Large Cap } \\
\text { Value }\end{array}$ & $\begin{array}{c}\text { Large Cap } \\
\text { Growth }\end{array}$ & \\
\hline Number of Data Points & & & 6 & 6 & \\
\hline Mean Monthly Return & & & -3.425 & -2.622 & \\
\hline Mean Quarterly Sharpe Ratio & & & 0.748 & 0.394 & \\
\hline Standard Deviation & & & 0.516 & 0.440 & \\
\hline Variance & & & 0.267 & 0.194 & \\
\hline P-Value & & & & & 0.367 \\
\hline
\end{tabular}

Table 4 (Hypothesis 4) provides a comparison of the mean monthly returns, mean quarterly Sharpe Ratios, the standard deviations, and the variances for the CRSP Large Cap Value Index against the CRSP Large Cap Growth Index for the 2009-2019 time period of the study. The mean monthly return for the period was larger for the Large Cap Growth Index at 1.340 as compared to the Large Cap Value Index return of 1.222 .

The mean quarterly Sharpe Ratio for the period for the growth category was lower than the value category where the growth category Sharpe Ratio was 0.126 as compared to 1.248 for the value category. The standard deviation and the variance for the value category were 3.901 and 15.221 , respectively, whereas for the growth category they were .694 and 1.006, respectively. 
TABLE 4

NUMBER OF DATA POINTS, MONTHLY RETURNS, SHARPE RATIOS, STANDARD

DEVIATIONS, VARIANCES, AND P-VALUES: LARGE CAP VALUE INDEX VERSUS LARGE CAP GROWTH INDEX (2009-2019)

\begin{tabular}{|c|c|c|c|c|c|}
\hline $\begin{array}{c}\text { Number/Returns/Ratios/ } \\
\text { Standard Deviation/Variance/ } \\
\text { P-Value }\end{array}$ & $\begin{array}{l}\text { Hypothesis } \\
\text { Number }\end{array}$ & $\begin{array}{l}\text { Time } \\
\text { Period }\end{array}$ & Index & Index & P-Value \\
\hline & $\mathrm{H} 4_{0}$ & $\begin{array}{l}2009- \\
2019\end{array}$ & $\begin{array}{l}\text { Large Cap } \\
\text { Value }\end{array}$ & $\begin{array}{l}\text { Large Cap } \\
\text { Growth }\end{array}$ & \\
\hline Number of Data Points & & & 41 & 41 & \\
\hline Mean Monthly Return & & & 1.222 & 1.340 & \\
\hline Mean Quarterly Sharpe Ratio & & & 1.248 & 0.126 & \\
\hline Standard Deviation & & & 3.901 & 0.694 & \\
\hline Variance & & & 15.221 & 1.006 & \\
\hline P-Value & & & & & 0.791 \\
\hline
\end{tabular}

\section{Results of the Study}

Bull Market (Hypothesis 1)

Quarterly Sharpe ratios were calculated from Monthly returns for the CRSP Large Cap Value Index and the CRSP Large Cap Growth Index for the period October 2002 to June 2019 representing 66 periods.

Appendix A shows the Kolmogorov Smirnov-test (KS-test) for normality, the Shapiro-Wilk test, and the Wilcoxon Signed Rank test for variance results for the time period addressed in the study. The KS-test and Shapiro-Wilk test indicated a non normal distribution for the period; therefore, the Wilcoxon Signed Rank test for variance was conducted as identified in the study's methodology section. The p-value for the period was 0.762 . Given these results, the null hypothesis of the time period was retained. That is, the CRSP Large Cap Value Sharpe ratio was not significantly greater than the CRSP Large Cap Growth Sharpe ratio for the period.

\section{Bull Market (Hypothesis 2)}

Quarterly Sharpe ratios were calculated from monthly returns for the CRSP Large Cap Value Index and the CRSP Large Cap Growth Index for the period October 2002 to September 2007, representing 19 periods.

Appendix B shows the KS-test for normality, the Shapiro-Wilk test, and the Wilcoxon Signed Rank test for variance results for the time period addressed in the study. The KS-test and Shapiro-Wilk test indicated a non normal distribution for the period; therefore, the Wilcoxon Signed Rank test for variance was conducted as identified in the study's methodology section. The p-value for the period was 0.334 . Given these results, the null hypothesis for the time period was retained. Therefore, the CRSP Large Cap Value Index Sharpe ratio was not significantly greater than the CRSP Large Cap Growth Index Sharpe ratio for the time period.

\section{Bear Market (Hypothesis 3)}

Quarterly Sharpe ratios were calculated from monthly returns for the CRSP Large Cap Value Index and the CRSP Large Cap Growth Index for the period October 2007 to March 2009 representing 6 periods.

Appendix C shows the KS-test for normality, the Shapiro-Wilk test, and the Wilcoxon Signed Rank test for variance results for the time period addressed in the study. The KS-test and the Shapiro-Wilk test indicated a normal distribution for the period; therefore, the F-test for variance was conducted as 
identified in the study's methodology section. The p-value for the period was 0.367 . Given these results, the null hypothesis for the time period was retained. Therefore, the CRSP Large Cap Value Index Sharpe ratio was not significantly greater than the CRSP Large Cap Growth Index Sharpe ratio for the time period.

\section{Bull Market (Hypothesis 4)}

Quarterly Sharpe ratios were calculated from monthly returns for the CRSP Large Cap Value Index and the CRSP Large Cap Growth Index for the period April 2009 to June 2019, representing 41 periods.

Appendix D shows the KS-test for normality, the Shapiro-Wilk test, and the Wilcoxon Signed Rank test for variance results for the time period addressed in the study. The KS-test and the Shapiro-Wilk test indicated a non normal distribution for the period; therefore, the Wilcoxon Signed Rank test for variance was conducted as identified in the study's methodology section. The p-value for the period was 0.791 . Given these results, the null hypothesis for the time period was retained. Therefore, the CRSP Large Cap Value Index Sharpe ratio was not significantly greater than the CRSP Large Cap Growth Index Sharpe ratio for the time period.

\section{CONCLUSION}

The current bull market has become the longest running in history and continues to set new all time highs in the Dow Jones Industrial Average, the S\&P 500 and the NASDAQ as well as several other indices. Given the fear of investors looking for a market top, the findings of the study and the previous research, investors may want to consider asset allocation of funds utilizing a combination of a value and growth investment strategy to mitigate portfolio risk. This allocation should, however, consider the associated risk with any given investment and the long-term trends of the market.

This study found that on a risk-adjusted basis in the four hypotheses tested the mean quarterly Sharpe Ratios were not significantly higher for the CRSP Large Cap Value Index Sharpe ratio as compared to the CRSP Large Cap Growth Index. Previous studies have indicated value will out perform growth on a riskadjusted basis over time (Wang, 2011). For the period tested, growth out performs value, but when considering risk-adjusted returns, the findings are not statistically significant.

The findings of this study added to the continued debate of value versus growth as an investment strategy. Recently there has been a resurgence of value stocks in the market place, but given the increase in bond prices and the progress in the U.S.-China trade talks this is not likely to continue (Mackintosh, 2019). As the market reaches new all time highs, managers will continue to seek protection for portfolio principal through a value strategy, but they must ensure they avoid the value trap.

\section{REFERENCES}

Arancibia, J. C. (2019, May 2). Growth vs. value stocks: This side of debate wins in ETF leaders. Investor's Business Daily; Los Angeles. Retrieved from http://search.proquest.com/docview/2218577914/abstract/BC5A059338AF4B1FPQ/1

Asness, C., Frazzini, A., Israel, R., \& Moskowitz, T. (2015). Fact, fiction, and value investing. Journal of Portfolio Management; New York, 42(1), 34-52.

Beukes, A. (2011). Value investing: International comparison. The International Business \& Economics Research Journal; Littleton, 10(5), 1-9.

Blazenko, G. W., \& Fu, Y. (2013). Value versus growth in dynamic equity investing. Managerial Finance; Patrington, 39(3), 272-305.

Braham, L. (2018). Growth vs. value: more divided than ever. Barron's; New York, NY, 98(12), 31.

Cronqvist, H., Siegel, S., \& Yu, F. (2015). Value versus growth investing: Why do different investors have different styles? Journal of Financial Economics, 117(2), 333-349.

Fama, E., \& French, K. (1992). The cross-section of expected returns. Journal of Finance, 47, 427-486.

Graham, B. (1973). The intelligent investor. New York, NY: Harper Business. 
Graham, B., \& Dodd, D. (1934). Security analysis. New York, NY: McGraw Hill Book Company.

Graham, J. (2018, October 4). Value vs. growth stocks: growth continues to crush value investing, but his big risk looms. Investor's Business Daily; Los Angeles. Retrieved from http://search.proquest.com/docview/2116174706/

Growth stocks get a boost. (2019, July 1). Wall Street Journal. Eastern Edition; New York, NY, pp. B5B8.

Hough, J. (2011, October 29). WEEKEND INVESTOR --- Upside: why value will beat growth. Wall Street Journal, Eastern Edition; New York, NY, p.B7.

Hulbert, M. (2018, July 9). Investing in funds \& ETFs: A quarterly analysis --- Fundamentals of investing: "Value" stocks aren't a bear-market cure --- Perceptions aside, there is no consistency in the performance of value vs. growth. Wall Street Journal, Eastern Edition; New York, NY, p.R7.

Jackson, A. L. (2017, October 22). Value vs. growth; Because the two investing styles complement each other; They can help add diversity to your portfolio when used together. Morning Call; Allentown, PA, p. P7.

Kábrt, T. (2015). The relationship between discounts and premiums and value investing theory. Procedia Economics and Finance, 25, 220-226.

Kok, U. W., Ribando, J., \& Sloan, R. (2017). Facts about formulaic value investing. Financial Analysts Journal; Charlottesville, 73(2), 81-99.

Mackintosh, J. (2019, July 15). A bargain hunter seeks hope in history. Wall Street Journal, Eastern Edition; New York, NY, p.B1.

Mackintosh, J. (2019, September 16). Value's rebound unlikely to last as disrupters hold edge. Wall Street Journal, Eastern Edition; New York, NY, p.B9.

Max, S. (2019). Value will beat growth again-someday. Barron's; New York, NY, 99(14). Retrieved from https://search-proquest-com.proxy.davenport.edu/docview/2206006353

Otuteye, E., \& Siddiquee, M. (2015). Overcoming cognitive biases: A heuristic for making value investing decisions. Journal of Behavioral Finance, 16(2), 140-149.

Patel, K. (2018). Explaining value vs. growth investing through accounting fundamentals. Financial Analysts Journal; Charlottesville, 74(4), 31-32.

Penman, S., \& Reggiani, F. (2018). Fundamentals of value versus growth investing and an explanation for the value trap. Financial Analysts Journal; Charlottesville, 74(4), 103-119.

Pettengill, G., Chang, G., \& Hueng, C. J. (2014). Choosing between value and growth in mutual fund investing. Financial Services Review; Atlanta, 23(4), 341-359.

Russolillo, S. (2018, February 16). A value proposition for value over growth. Wall Street Journal, Eastern Edition; New York, NY, p.B.11.

Strauss, L. C. (2015). When growth mirrors value. Barron's; New York, NY, 95(7), 11.

Wang, J. (2011). Impact of investment horizon on the performance of value versus growth styles and style allocation. Journal of Asset Management; London, 12(6), 438-446. 


\section{APPENDIX A}

Case Processing Summary

\begin{tabular}{lllllll}
\multicolumn{1}{c}{ Cases } & & & & \multicolumn{3}{c}{ Total } \\
& Valid & Missing & & N & Percent \\
Value & 66 & Percent & $\mathrm{N}$ & Percent & $\mathrm{N}$ & \\
Growth & 66 & $100.00 \%$ & 0 & $0.00 \%$ & 66 & $100.00 \%$ \\
& & $100.00 \%$ & 0 & $0.00 \%$ & 66 & $100.00 \%$
\end{tabular}

Descriptive Statistics

\begin{tabular}{|c|c|c|c|c|}
\hline \multirow[t]{15}{*}{ Value } & \multirow{5}{*}{$\begin{array}{l}\text { Mean } \\
95 \% \text { Confidence Interval } \\
\text { for Mean }\end{array}$} & & 0.9293 & 0.39318 \\
\hline & & Lower & & \\
\hline & & Bound & 0.1441 & \\
\hline & & Upper & & \\
\hline & & Bound & 1.7146 & \\
\hline & 5\% Trimmed Mean & & 0.5608 & \\
\hline & Median & & 0.3943 & \\
\hline & Variance & & 10.203 & \\
\hline & Std. Deviation & & 3.19421 & \\
\hline & Minimum & & -3.88 & \\
\hline & Maximum & & 24.26 & \\
\hline & Range & & 28.13 & \\
\hline & Interquartile Range & & 1.18 & \\
\hline & Skewness & & 6.164 & 0.295 \\
\hline & Kurtosis & & 45.057 & 0.582 \\
\hline \multirow[t]{14}{*}{ Growth } & Mean & & 0.4943 & 0.11386 \\
\hline & 95\% Confidence Interval & Lower & & \\
\hline & for Mean & Bound & 0.2669 & \\
\hline & & $\begin{array}{l}\text { Upper } \\
\text { Bound }\end{array}$ & 0.7217 & \\
\hline & $5 \%$ Trimmed Mean & & 0.4491 & \\
\hline & Median & & 0.3033 & \\
\hline & Variance & & 0.856 & \\
\hline & Std. Deviation & & 0.92503 & \\
\hline & Minimum & & -1.21 & \\
\hline & Maximum & & 3.56 & \\
\hline & Range & & 4.77 & \\
\hline & Interquartile Range & & 0.87 & \\
\hline & Skewness & & 0.89 & 0.295 \\
\hline & Kurtosis & & 1.191 & 0.582 \\
\hline
\end{tabular}


Tests of Normality

\begin{tabular}{lllllll} 
& Kolmogorov-Smirnov & & \multicolumn{3}{c}{ Shapiro- } \\
& Statistic & df & Sig. & Wilk & \\
Value & 0.256 & 66 & 0 & 0.429 & 66 & 0 \\
Growth & 0.13 & 66 & 0.007 & 0.947 & 66 & 0.007
\end{tabular}

a Lilliefors Significance Correction

Descriptive Statistics

$\begin{array}{llllll} & \mathrm{N} & \text { Mean } & \text { Std. Deviation } & \text { Minimum } & \text { Maximum } \\ \text { Value } & 66 & 0.9293 & 3.19421 & -3.88 & 24.26 \\ \text { Growth } & 66 & 0.4943 & 0.92503 & -1.21 & 3.56\end{array}$

Ranks

Growth - Value

$\begin{array}{llll}\text { Negative } & \text { N } & \text { Mean Rank } & \begin{array}{l}\text { Sum of } \\ \text { Ranks }\end{array} \\ \text { Ranks } & \text { 36a } & 32.03 & 1153 \\ \text { Positive Ranks } & \text { 30b } & 35.27 & 1058 \\ \text { Ties } & \text { 0c } & & \\ \text { Total } & 66 & & \end{array}$

a Growth $<$ Value

b Growth $>$ Value

c Growth $=$ Value

Test Statistics

Growth -

Value

Z

$-.303 b$

Asymp. Sig. (2-tailed) $\quad 0.762$

a Wilcoxon Signed Ranks

Test

b Based on positive ranks. 


\section{APPENDIX B}

Case Processing Summary

\section{Cases \\ Valid \\ $\mathrm{N}$}

Value $\quad 19$

Growth 19

Descriptive

Statistics

Value

Mean
95\% Confidence Interva
for Mean

5\% Trimmed Mean

Median

Variance

Std. Deviation

Minimum

Maximum

Range

Interquartile Range

Skewness

Kurtosis

Growth
Mean

95\% Confidence Interval

for Mean

5\% Trimmed Mean

Median

Variance

Std. Deviation

Minimum

Maximum

Range

Interquartile Range

Skewness

Kurtosis

\begin{tabular}{lllll} 
& Missing & \multicolumn{3}{c}{ Total } \\
Percent & $\mathrm{N}$ & Percent & $\mathrm{N}$ & Percent \\
$100.00 \%$ & 0 & $0.00 \%$ & 19 & $100.00 \%$ \\
$100.00 \%$ & 0 & $0.00 \%$ & 19 & $100.00 \%$
\end{tabular}

Std.

Statistic Error

$0.7547 \quad 0.302$

Lower

Bound $\quad 0.1202$

Upper

Bound $\quad 1.3891$

0.6326

0.3748

1.733

1.31639

$-0.87$

4.58

5.45

1.44

$1.686 \quad 0.524$

$2.931 \quad 1.014$

$\begin{array}{ll}0.3347 & 0.14797\end{array}$

Lower

Bound $\quad 0.0239$

Upper

Bound

0.6456

0.29

0.3017

0.416

0.64498

$-0.63$

2.1

2.73

0.4

$1.189 \quad 0.524$

$2.522 \quad 1.014$ 
Tests of Normality

\begin{tabular}{lllllll}
\multicolumn{2}{r}{ Kolmogorov-Smirnov } & \multicolumn{5}{c}{ Shapiro-Wilk } \\
& Statistic & df & Sig. & Statistic & df & Sig. \\
Value & 0.285 & 19 & 0 & 0.819 & 19 & 0.002 \\
Growth & 0.224 & 19 & 0.013 & 0.882 & 19 & 0.024 \\
a Lilliefors Significance Correction & & & & &
\end{tabular}

Descriptive Statistics

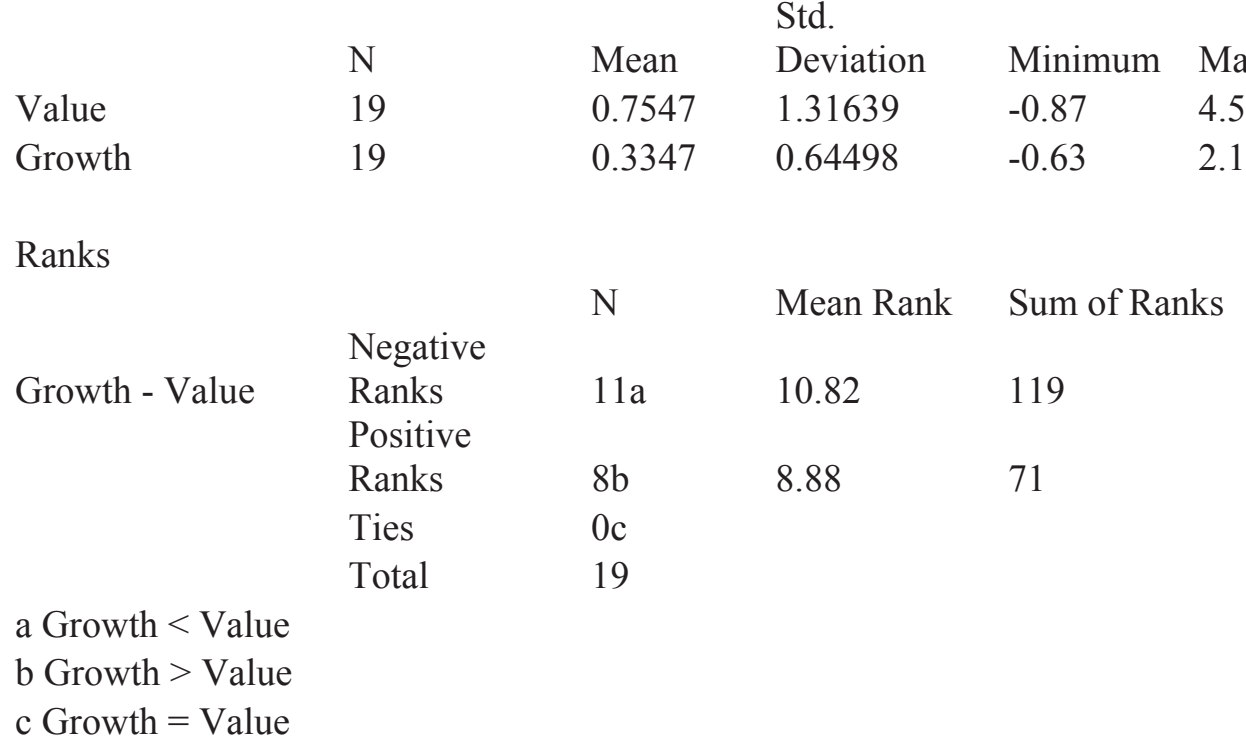

Test Statistics

$\begin{array}{ll} & \text { Growth - Value } \\ \mathrm{Z} & -.966 \mathrm{~b}\end{array}$

Asymp. Sig. (2-

tailed)

0.334

a Wilcoxon Signed Ranks Test

$\mathrm{b}$ Based on positive ranks. 


\section{APPENDIX C}

Case Processing Summary

Cases

Valid

$\mathrm{N}$

Value 6

Growth 6

\begin{tabular}{lllll} 
& Missing & \multicolumn{3}{c}{ Total } \\
Percent & $\mathrm{N}$ & Percent & $\mathrm{N}$ & Percent \\
$100.00 \%$ & 0 & $0.00 \%$ & 6 & $100.00 \%$ \\
$100.00 \%$ & 0 & $0.00 \%$ & 6 & $100.00 \%$
\end{tabular}

Descriptive Statistics

Value Mean

95\% Confidence Interval for

Mean

5\% Trimmed Mean

Median

Variance

Std. Deviation

Minimum

Maximum

Range

Interquartile Range

Skewness

Kurtosis

Growth Mean

95\% Confidence Interval for

Mean

5\% Trimmed Mean

Median

Variance

Std. Deviation

Minimum

Maximum

Range

Interquartile Range

Skewness

Kurtosis
Std.

Statistic Error

$-0.7483 \quad 0.21077$

Lower

Bound

Upper

Bound

$-1.2901$

$-0.2065$

$-0.7223$

$-0.6069$

0.267

0.51628

$-1.68$

$-0.29$

1.39

0.73

$\begin{array}{ll}-1.367 & 0.845\end{array}$

$1.758 \quad 1.741$

$-0.3942 \quad 0.17964$

Lower

Bound

$-0.8559$

Upper

Bound

0.0676

$-0.3942$

$-0.4028$

0.194

0.44002

$-0.89$

0.1

0.99

0.85

$0.015 \quad 0.845$

$-2.793 \quad 1.741$ 
Tests of Normality

\begin{tabular}{|c|c|c|c|c|c|c|}
\hline \multicolumn{4}{|c|}{ Kolmogorov-Smirnov } & \multicolumn{3}{|c|}{ Shapiro-Wilk } \\
\hline & Statistic & df & Sig. & Statistic & $\mathrm{df}$ & Sig. \\
\hline Value & 0.238 & 6 & $.200 *$ & 0.859 & 6 & 0.186 \\
\hline Growth & 0.243 & 6 & $.200 *$ & 0.86 & 6 & 0.19 \\
\hline \multicolumn{7}{|c|}{$\begin{array}{l}\text { * This is a lower bound of the true significance. } \\
\text { a Lilliefors Significance Correction }\end{array}$} \\
\hline \multicolumn{7}{|c|}{ F-Test Two-Sample for Variances } \\
\hline & & \multicolumn{2}{|c|}{ Variable 1} & \multicolumn{3}{|c|}{ Variable 2} \\
\hline Mea & & \multicolumn{2}{|c|}{-0.748336245} & \multicolumn{3}{|c|}{-0.394163496} \\
\hline Vari & & \multicolumn{2}{|c|}{0.266548116} & \multicolumn{3}{|c|}{0.193617816} \\
\hline \multicolumn{2}{|c|}{ Observations } & \multicolumn{2}{|l|}{6} & \multicolumn{3}{|l|}{6} \\
\hline \multicolumn{2}{|c|}{ df } & \multicolumn{2}{|l|}{5} & \multicolumn{2}{|l|}{5} & \\
\hline \multicolumn{2}{|l|}{$\mathrm{F}$} & \multicolumn{2}{|c|}{1.376671431} & & & \\
\hline \multicolumn{2}{|c|}{$\mathrm{P}(\mathrm{F}<=\mathrm{f})$ one-tail } & \multicolumn{2}{|c|}{0.367155249} & & & \\
\hline \multicolumn{2}{|c|}{ F Critical one-tail } & \multicolumn{2}{|c|}{5.050329058} & & & \\
\hline
\end{tabular}




\section{APPENDIX D}

Case Processing Summary

Cases

Valid

$\mathrm{N}$

Value 41

Growth 41

\begin{tabular}{lllll} 
& Missing & \multicolumn{3}{c}{ Total } \\
Percent & $\mathrm{N}$ & Percent & $\mathrm{N}$ & Percent \\
$100.00 \%$ & 0 & $0.00 \%$ & 41 & $100.00 \%$ \\
$100.00 \%$ & 0 & $0.00 \%$ & 41 & $100.00 \%$
\end{tabular}

Descriptive Statistics

Value Mea

95\% Confidence Interval

for Mean

5\% Trimmed Mean

Median

Variance

Std. Deviation

Minimum

Maximum

Range

Interquartile Range

Skewness

Kurtosis

Growth Mean

95\% Confidence Interval

for Mean

5\% Trimmed Mean

Median

Variance

Std. Deviation

Minimum

Maximum

Range

Interquartile Range

Skewness

Kurtosis
Std.

Statistic Error

Lower

Bound $\quad 0.0244$

Upper

Bound

2.4872

0.7247

0.5696

15.221

3.90139

$-3.88$

24.26

28.13

1.09

5.335

$31.99 \quad 0.724$

$0.6982 \quad 0.15664$

Lower

Bound $\quad 0.3816$

Upper

Bound $\quad 1.0148$

0.6616

0.5369

1.006

1.00298

$-1.21$

3.56

4.77

1.28

$\begin{array}{ll}0.645 & 0.369\end{array}$

$0.718 \quad 0.724$ 
Tests of Normality

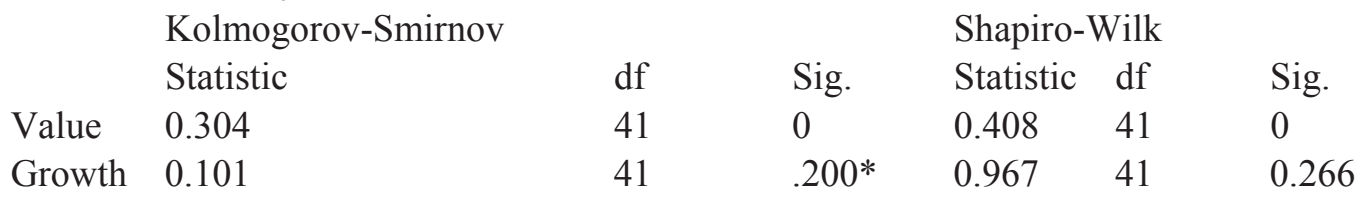

* This is a lower bound of the true significance.

a Lilliefors Significance Correction

Descriptive Statistics

\begin{tabular}{|c|c|c|c|c|c|}
\hline & $\mathrm{N}$ & Mean & $\begin{array}{l}\text { Std. } \\
\text { Deviation }\end{array}$ & Minimum & Maximum \\
\hline Value & 41 & 1.2558 & 3.90139 & -3.88 & 24.26 \\
\hline Growth & 41 & 0.6982 & 1.00298 & -1.21 & 3.56 \\
\hline \multicolumn{6}{|l|}{ Ranks } \\
\hline & & $\mathrm{N}$ & Mean Rank & \multicolumn{2}{|c|}{ Sum of Ranks } \\
\hline \multirow[t]{4}{*}{ Growth - Value } & $\begin{array}{l}\text { Negative } \\
\text { Ranks } \\
\text { Positive }\end{array}$ & $23 a$ & 19.61 & 451 & \\
\hline & Ranks & $18 \mathrm{~b}$ & 22.78 & 410 & \\
\hline & Ties & $0 \mathrm{c}$ & & & \\
\hline & Total & 41 & & & \\
\hline \multicolumn{6}{|c|}{$\begin{array}{l}\text { a Growth }<\text { Value } \\
\text { b Growth }>\text { Value } \\
\text { c Growth }=\text { Value }\end{array}$} \\
\hline \multicolumn{6}{|l|}{ Test Statistics } \\
\hline & \multicolumn{2}{|c|}{ Growth - Value } & & & \\
\hline Z & \multicolumn{2}{|l|}{$-.266 b$} & & & \\
\hline $\begin{array}{l}\text { Asymp. Sig. (2- } \\
\text { tailed) }\end{array}$ & \multicolumn{2}{|l|}{0.791} & & & \\
\hline \multicolumn{3}{|c|}{ a Wilcoxon Signed Ranks Test } & & & \\
\hline
\end{tabular}

